\title{
The effect of DanAvl Duroc and Pulawska boars in crossbred with DanAvl Hybrid on meat quality of finishing pigs
}

\author{
Artur Rybarczyk ${ }^{1}$, Robert Moroch ${ }^{1}$ and Daniel Polasik ${ }^{2}$ \\ ${ }^{1}$ West Pomeranian University of Technology, Department of Immunology, Microbiology and Physiological Chemistry, \\ Piastów 45, 70-310 Szczecin, Poland \\ ${ }^{2}$ West Pomeranian University of Technology, Department of Genetics and Animal Breeding, Piastów 45, 70-310 Szczecin, Poland \\ e-mail: artur.rybarczyk@zut.edu.pl
}

\begin{abstract}
The research was aimed at determining the physicochemical and sensory properties of the $\mathrm{m}$. longissimus lumborum at DanAvl Hybrid (Landrace - Yorkshire) fatteners and derived from DanAvl Hybrid sows and DanAvl Duroc and Pulawska boars. Fatteners derived from DanAvl Duroc boars were characterized by better meat quality compared to DanAvl Hybrids and their hybrids with Pulawska breed as evidenced by higher pH in 24-96 h post mortem (p.m.), higher sensory evaluation of juiciness, tenderness and flavor as well as lower shear force at lower content of total protein and higher content of intramuscular fat (IMF). However, DanAvl Hybrid fatteners were characterized by poorer meat quality, i.e. higher color lightness ( $\left.L^{*}\right)$ and higher drip loss both from fresh and thawed meat compared to those derived from DanAvl Duroc and Pulawska boars. Meat of fatteners after Pulawska breed was characterized by the highest redness ( $\left.a^{*}\right)$, and that after DanAvl Duroc breed, the lowest yellowness ( $\left.b^{*}\right)$ and saturation $\left(C^{*}\right)$.
\end{abstract}

Key words: crossbreeding, Danish and Polish breeds, pork

\section{Introduction}

In the DanAvl cross-breeding program (DanBred International), Danish Yorkshire (Y) and Danish Landrace (L) breeds are used, which are perfect for the production of gilts. DanAvl Hybrid results from the first cross-breeding of maternal line ( $\mathrm{LY} / \mathrm{YL})$. Studies have shown that DanAvl Hybrid gilts have high fertility and prolificacy, give birth to 1.5 piglets per litter more than pure DanAvl Landrace and Yorkshire breeds, as well as have good maternal instinct (Kasprzyk and Łucki 2014). Duroc is a cross-breeding reproducer that has very good mating abilities (Chang et al. 2017). Research conducted by Danish National Committee for Pig Production, when comparing different breed combinations, has shown that pure DanAvl Duroc breed provides the best economic effects (Nielsen et al. 2013). The use of Duroc breed as a paternal component in cross-breeding in many pork production programs is justified by their high resistance to stress and thus good meat quality, which also results from the fact that pigs of this breed are characterized by IMF content, which is known to positively affect, among others, the sensory values of pork and lower shear force (Koćwin-Podsiadła et al. 2004a, Krzęcio et al. 2004, Grześ et al. 2005, Juárez et al. 2009). However, quality of carcass and meat of fatteners after pure-breed duroc boars may vary depending on which farm/program they come from (Cilla et al. 2006, Sieczkowska et al. 2010).

In Poland, in the production of high-quality pork, particular attention is paid to the breeds of domestic pigs, i.e. Pulawska, Zlotnicka White and Zlotnicka Spotted. These breeds have been subjected to intensive breeding for years, therefore, it has allowed maintaining high quality values, including darker, more desirable color of meat, specific taste and suitability for production of long-lasting cured meat. Research shows that meat of these pigs often shows an advantage in terms of quality traits in relation to that obtained from pigs of other breeds subjected to intensive breeding (Babicz et al. 2013, Szulc and Skrzypczak 2015, Wojtysiak et al. 2016, Cebulska et al. 2018, Debrecéni et al. 2018). Previous research indicates the beneficial impact of Pulawska breed in cross-breeding with Polish Large White (PLW) and Polish Landrace (PL) (Florowski et al. 2008) and Duroc (Babicz et al. 2009) on technological and sensory meat quality of fatteners. However, there are no studies, in which the possibility of using the native Polish Pulawska breed for cross-breeding with Danish breeds in the production of high-quality meat would be analyzed. Concerning the above, it can be assumed that using both Duroc and Pulawska boars crossbred with fertile and prolific DanAvl Hybrid sows allows for obtaining meat that is technologically and culinary of high quality.

The aim of the research was to determine physicochemical and sensory properties of longissimus lumborum muscle of hybrid fatteners derived from Landrace and Yorkshire (DanAvl Hybrid) breeds and their hybrids after purebred DanAvl Duroc and Pulawska boars. 


\title{
Material and methods
}

\author{
Animals
}

The research was carried out in the summer season using three groups of crossbred fatteners, that came from one company dealing with the production of pigs in the Pomeranian Voivodeship (Poland). The study involved DanAvl Hybrid fatteners and fatteners derived from the offspring of DanAvl Hybrid sows, (Landrace - Yorkshire; LY) the pure-bred boars DanAvl Duroc from DanBred International and the pure-bred boars Pulawska which were housed under the same environmental conditions with a non-bedding system (on grates). All pigs received drinking water and the same complete feed mixture for fatteners ad libitum system.

At a defined week, each group of $50 \mathrm{LY}$ sows were inseminated by the selected boars, i.e.: DanAvl Duroc (5); Pulawska (3); Yorkshire/Landrace (3). The Pulawska boars' semen came from the farm which fulfill Pulawska Breed Genetic Resources Protection Program requirements (zamojski district, lubelskie voivodeship, Poland). According the performance testing ${ }_{2}$ Pulawska boars reached the growth in fattening period of $625 \mathrm{~g} /$ day and meatiness of pig carcasses $-55.4 \%$.

After reaching a body weight of about $112 \mathrm{~kg}$, fatteners from a given group (in the number of 60), non-mixing of unfamiliar pigs, were all transported to Meat Plants (Table 1). All three groups of fattening pigs were transported by the same means of transport, at which the temperature was in the range of $22-24^{\circ} \mathrm{C}$. After unloading, the pigs were given to 15 hours of pre-slaughter rest at an ambient temperature of $16-18{ }^{\circ} \mathrm{C}$; the duration of fasting time before slaughter was 24 hours.

Table 1. Experiment layout

\begin{tabular}{lccc}
\hline Numbers & \multicolumn{3}{c}{ Group of pigs } \\
\hline & DanAvl Hybrid (LY) & Pulawska $\times$ LY & DanAvl Duroc $\times$ LY \\
\cline { 2 - 4 } Fatteners & 60 & 60 & 60 \\
Carcasses & 30 & 28 & 30 \\
Gilts/Barrows & $12 / 18$ & $14 / 14$ & $15 / 15$ \\
\hline
\end{tabular}

\section{Carcass and meat quality}

On the slaughter line, after the pigs were stunned (Butina $\mathrm{CO}_{2}$ gas stunning system, Denmark), lean meat percentage in the carcass, was non-invasively ultrasonically measured (AutoFom, SFK Technology, Denmark) and sex of fatteners was determined. Before cooling, the hot carcass weight was determined with an accuracy of $100 \mathrm{~g}$. Next, the carcasses were progressively chilled for $24 \mathrm{~h}$. At first, they were cooled at a temperature of $+1^{\circ} \mathrm{C}$ for 7 $-8 \mathrm{~h}$, and then after filling the store, the carcasses were cooled at a temperature between $-3{ }^{\circ} \mathrm{C}$ and $-4{ }^{\circ} \mathrm{C}$ for 6 $-7 \mathrm{~h}$, and then at $4-6{ }^{\circ} \mathrm{C}$ for the rest of the time (about $10 \mathrm{~h}$ ). In a cold store, based on the identified sex and a defined hot carcass weight, 30 carcasses of similar weight $(90 \pm 5 \mathrm{~kg})$ and similar share of gilts and barrows were selected from each group.

After cooling the carcasses, during cutting the right halves into the basic elements, the $m$. longissimus lumborum (LL) samples were taken for testing. The LL muscle samples, packaged in labeled foil pouches, were transported in thermoses to the laboratory and stored in a refrigerator at $4{ }^{\circ} \mathrm{C}$. Then, 3 slices $3 \mathrm{~cm}$ thick were cut out of the muscle samples starting from the head section, to determine the drip loss, $\mathrm{pH}$ and color characteristics. The remainder of the muscle was packed into labeled plastic bags and frozen at $-19{ }^{\circ} \mathrm{C}$ for approximately one month to determine water binding, shear force and sensory evaluation.

The following qualitative determinations were made on fresh LL muscle:

The $\mathrm{pH}$ was measured $35 \mathrm{~min}, 3 \mathrm{~h}$ and $24 \mathrm{~h}$ (in a cold room, right halves), $48 \mathrm{~h}$ and $96 \mathrm{~h} \mathrm{p.m.} \mathrm{using} \mathrm{portable} \mathrm{pH-me-}$ ter equipped with a temperature sensor (CP-411 pH-meter, Elmetron, Poland).

Electrical conductivity was determined at 2 and $24 \mathrm{~h}$ p.m. $\left(\mathrm{EC}_{2}\right.$ and $\left.\mathrm{EC}_{24}\right)$ in a cold room on the right halves using the LF-Star device (Ingenieurbüro Matthäus, Germany). 
Drip loss was determined by the method of Prange et al. (1977). In 24 h p.m., muscle samples weighing $50 \mathrm{~g}$ (cut out from the middle part of the $3 \mathrm{~cm}$ thick slice) were put in plastic bags and stored at $4{ }^{\circ} \mathrm{C}$. Drip loss was defined as $\%$ loss in mass after 1 day ( 48 h p.m.) and 3 days (96 h p.m.) of storage.

The measurement of color features was performed on freshly cut muscle slices 24 and $48 \mathrm{~h}$ p.m., after 20 min blooming period at $4{ }^{\circ} \mathrm{C}$, by determining the lightness $\left(L^{*}\right)$, redness $\left(a^{*}\right)$, yellowness $\left(b^{*}\right)$, chroma $\left(C^{*}\right)$ and hue $\left(h^{\circ}\right)$, by means of a HunterLab Mini Scan XE Plus 45/0 (HunterLab Inc., Virginia, U.S.) with a standard illuminant D65 and $10^{\circ}$ Standard Observer.

\section{Water losses during thawing and cooking}

A fragment of $L L$ muscle (about $300 \mathrm{~g}$ ) was removed from the freezer, weighed (pre-thaw weight), thawed at $4{ }^{\circ} \mathrm{C}$ for about $24 \mathrm{~h}$ and re-weighed (pre-cook weight). The sample were heated in water at $80-81^{\circ} \mathrm{C}$ in an oven until reaching an internal temperature of $72{ }^{\circ} \mathrm{C}$ inside the meat samples and were then subjected to shear force and sensory evaluation after cooling to $20^{\circ} \mathrm{C}$ and weighted (post-cook weight).

\section{Shear force and sensory evaluation}

Shear force was measured using a Warner-Bratzler apparatus (WB) manufactured at the Baking Industry Research Centre (Bydgoszcz, Poland). Cylinder-shaped meat samples cut out with a cork borer with a diameter of $1.0 \mathrm{~cm}$ (along the muscle fibers) were placed in a triangular recess under the five blades of the tenderness measuring instrument, which then recorded the maximum force (expressed in kilograms) required for cutting through the meat. The final result for each sample was the average of three consecutive trials.

Sensory evaluation of the LL samples was performed to determine their color, aroma, tenderness, juiciness and flavor. Samples had approximately equal sizes (about $25 \mathrm{~g}$ ) and were placed in lidded one ounce glass jars labeled with three digit random codes and held in a water bath $\left(54^{\circ} \mathrm{C}\right)$ until presented to the panelists. The analysis was conducted in rooms at daylight and at a room temperature $\left(20^{\circ} \mathrm{C}\right)$. To neutralize the taste, each person received hot tea without sugar between the assessments of samples. This evaluation was performed in 9 sessions by a team of 5 trained individuals using a 5 -point scale ( $1=$ unacceptable and $5=$ very acceptable) according to ISO 4121:2003 and ISO 8586:2012. During the two sessions that took place each day, all panelists received, at the same time, 10 coded samples.

\section{Proximate analysis}

The basic chemical composition of LL muscles was determined in accordance with the official analytical methods of the AOAC (2006): moisture content by the oven-drying of $2 \mathrm{~g}$ samples at $102{ }^{\circ} \mathrm{C}$ to a constant weight $(950.46 \mathrm{~B}$, see p.39.1.02); crude protein content by the classical macro-Kjeldahl method (992.15, see p.39.1.16) and intramuscular fat content by petroleum ether extraction using a Soxhlet apparatus (960.39 (a), see p.39.1.05). The total mineral (ash) content was determined by incineration at $550{ }^{\circ} \mathrm{C}(923.03$, see p.32.1.05).

\section{Polymorphism of the RYR1 gene}

Genomic DNA was extracted from muscle samples using GeneMATRIX Tissue DNA Purification Kit (EURx, Poland). The RYR1 polymorphism was analyzed by polymerase chain reaction-restriction fragment length polymorphism method (PCR-RFLP) using following primer sequences: RYR1_F 5'-TCCAGTTTGCCACAGGTCCTACCA-3'; RYR1_R5'-ATTCACCGGAGTGGAGTCTCTGAG-3' (Ruan et al. 2013). Identification of the stress sensitivity gene (RYR1) revealed the occurrence of individuals with heterozygous genotype $(C T)$ only in the group of fatteners derived from Pulawska breed boars $(n=2)$. In the remaining groups, all fatteners were free from the $T$ allele at the RYR1 locus. Therefore, we removed individuals with $C T / R Y R 1$ genotype from further analysis, which allowed for analyzing the quality traits of the carcass and meat only at fatteners with genotype $C C / R Y R 1$.

\section{Statistical analysis}

The obtained data was analysed statistically (Statistica 13.1 PL), using the least squares method of the GLM procedure according to the following linear model:

$$
\mathrm{Y}_{\mathrm{ijk}}=\mu+\mathrm{a}_{\mathrm{i}}+\mathrm{b}_{\mathrm{j}}+b\left(\mathrm{x}_{\mathrm{ijk}}-\bar{x}\right)+\mathrm{e}_{\mathrm{ijk}}
$$


where: $Y_{i j k}$ - trait measured; $\mu$-the overall mean; $a_{i}$ - the effect of breed $(i=1,2,3) ; b_{j}-$ the effect of $\operatorname{sex}(j=1$, 2); $\beta$ - linear regression coefficient for hot carcass weight; $x_{i j k}$ - hot carcass weight of ijk-th individual included as covariable; $\mathrm{e}_{\mathrm{ijk}}$ - the random error.

The detailed comparison of mean least squares (LSQ) for the analysed breed was done using a Tukey's test. The tables show LSQ and their standard errors. In the statistical analysis, the relationship between fattening pigs (full sibs and half sibs) was not taken into account.

\section{Results \\ Production results and chemical composition of meat}

On the grounds of the information from the farm, the fattening time of DanAvl Hybrid fatteners and their crossbreed with Duroc breed was similar and came to 79 days (age 159 days). During the period, the average weight gain was about $1075 \mathrm{~g}$. The fattening of crossbred LY sows with Pulawska boars was longer and lasted 99 days (age 179 days). The average weight gain was about $850 \mathrm{~g}$ during this period.

In the statistical model adopted for the analysis, we took into account the influence of the hot carcass weight as we found significant differences between analyzed groups of fatteners in this respect (Table 2).

Table 2. Carcass quality and basic chemical composition

\begin{tabular}{lccc}
\hline Traits & \multicolumn{3}{c}{ Group of pigs } \\
\hline & DanAvl Hybrid (LY) & Pulawska $\times$ LY & DanAvl Duroc $\times$ LY \\
\cline { 2 - 4 } Hot carcass weight (kg) & $88.40^{\mathrm{B}} \pm 3.16$ & $90.53^{\mathrm{A}} \pm 1.68$ & $88.03^{\mathrm{B}} \pm 1.41$ \\
Meatiness (\%) & $57.91^{\mathrm{ab}} \pm 1.58$ & $58.29^{\mathrm{a}} \pm 2.75$ & $57.10^{\mathrm{b}} \pm 1.96$ \\
Total protein (\%) & $21.62^{\mathrm{B}} \pm 0.55$ & $22.09^{\mathrm{A}} \pm 0.42$ & $20.96^{\mathrm{C}} \pm 0.50$ \\
Intramuscular fat (\%) & $1.73^{\mathrm{B}} \pm 0.85$ & $1.53^{\mathrm{B}} \pm 0.55$ & $2.57^{\mathrm{A}} \pm 0.71$ \\
Dry matter (\%) & $25.34 \pm 0.75$ & $25.64 \pm 0.40$ & $25.53 \pm 0.84$ \\
Ash (\%) & $1.16 \pm 0.05$ & $1.18 \pm 0.03$ & $1.18 \pm 0.09$ \\
\hline
\end{tabular}

$\overline{\mathrm{A}, \mathrm{B}}$ Mean values marked by different large letters differ significantly at $p \leq 0.01{ }^{\mathrm{a,b}}$ Mean values marked by different small letters differ significantly at $p \leq 0.05$.

Based on the result analysis, we showed that fatteners after pure-breed DanAvl Duroc boars were characterized by significantly lower carcass meatiness in comparison to those after Pulawska boars ( $57.1 \%$ vs. $58.29 \%)$, and hybrids of Yorkshire with Landrace (DanAvl Hybrid) - the intermediate meatiness between these groups of fatteners. Analysis of basic chemical composition showed that the LL muscles of fatteners after DanAvl Duroc boars were characterized by significantly higher IMF content and lower total protein in relation to DanAvl Hybrids fatteners and their hybrids with Pulawska breed.

\section{Pork quality characteristics}

The study has shown that chilled carcasses of fatteners after DanAvl Duroc boars were characterized by significantly higher $\mathrm{pH}$ of $\mathrm{LL}$ muscle on various $p$.m. dates $\left(\mathrm{pH}_{24}, \mathrm{pH}_{48}, \mathrm{pH}_{96}\right)$ compared to DanAvl Hybrid and their hybrids with Pulawska breed (Table 3). Also, fatteners derived from DanAvl Duroc boars had better meat quality based on lower thaw loss and total fluid losses relative to DanAvl Hybrid pigs (Table 4).

Table 3. $\mathrm{pH}$ and electrical conductivity (EC)

\begin{tabular}{lccc}
\hline Traits & \multicolumn{3}{c}{ Group of pigs } \\
\hline & DanAvl Hybrid $(\mathrm{LY})$ & Pulawska $\times$ LY & DanAvl Duroc $\times$ LY \\
\cline { 2 - 3 } $\mathrm{pH}_{35 \mathrm{~min}}$ & $6.61 \pm 0.24$ & $6.59 \pm 0.21$ & $6.58 \pm 0.15$ \\
$\mathrm{pH}_{3}$ & $6.07 \pm 0.19$ & $6.01 \pm 0.25$ & $5.91 \pm 0.19$ \\
$\mathrm{pH}_{24}$ & $5.51^{\mathrm{B}} \pm 0.05$ & $5.50^{\mathrm{B}} \pm 0.08$ & $5.65^{\mathrm{A}} \pm 0.16$ \\
$\mathrm{pH}_{48}$ & $5.48^{\mathrm{B}} \pm 0.06$ & $5.50^{\mathrm{B}} \pm 0.09$ & $5.72^{\mathrm{A}} \pm 0.20$ \\
$\mathrm{pH}_{96}$ & $5.56^{\mathrm{B}} \pm 0.05$ & $5.51^{\mathrm{B}} \pm 0.07$ & $5.68^{\mathrm{A}} \pm 0.14$ \\
$\mathrm{EC}_{2}\left(\mathrm{mS} \mathrm{cm}^{-1}\right)$ & $3.49 \pm 0.78$ & $3.37 \pm 0.90$ & $3.49 \pm 1.03$ \\
$\mathrm{EC}_{24}\left(\mathrm{mS} \mathrm{cm}^{-1}\right)$ & $4.17 \pm 1.08$ & $4.44 \pm 1.68$ & $3.94 \pm 1.18$
\end{tabular}

$\overline{A, B}$ Mean values marked by different large letters differ significantly at $p \leq 0.01$. 


\begin{tabular}{|c|c|c|c|}
\hline \multirow[t]{2}{*}{ Traits } & \multicolumn{3}{|c|}{ Group of pigs } \\
\hline & DanAvl Hybrid (LY) & Pulawska $\times$ LY & DanAvl Duroc $\times$ LY \\
\hline fresh meat & & & \\
\hline drip loss ${ }_{24}(\%)$ & $3.54^{\mathrm{A}} \pm 0.83$ & $2.27^{B} \pm 0.85$ & $2.19^{\mathrm{B}} \pm 0.99$ \\
\hline 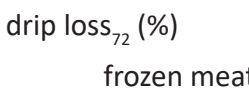 & $6.34^{\mathrm{A}} \pm 1.24$ & $4.94^{B} \pm 1.58$ & $4.37^{B} \pm 1.75$ \\
\hline Thawed loss (\%) & $11.26^{A} \pm 4.12$ & $9.66^{\mathrm{AB}} \pm 3.14$ & $7.72^{\mathrm{B}} \pm 3.49$ \\
\hline Cooked loss (\%) & $28.67 \pm 3.90$ & $28.19 \pm 2.65$ & $27.75 \pm 3.38$ \\
\hline Total fluid loss (\%) & $36.80^{A} \pm 2.83$ & $35.16^{\mathrm{AB}} \pm 2.62$ & $33.28^{\mathrm{B}} \pm 4.77$ \\
\hline
\end{tabular}

A,B Mean values marked by different large letters differ significantly at $p \leq 0.01$

In addition, fatteners after DanAvl Duroc and Pulawska boars were characterized by better quality of meat as compared to DanAvl Hybrid pigs, as evidenced by significantly lower drip loss determined after 24 and 72 hrs of refrigeration storage and lower lightness $\left(L^{*}\right)$ determined at both 24 and 48 hrs p.m. (Table 5).

\begin{tabular}{|c|c|c|c|}
\hline \multirow[t]{2}{*}{ Traits } & \multicolumn{3}{|c|}{ Group of pigs } \\
\hline & DanAvl Hybrid (LY) & Pulawska $\times$ LY & DanAvl Duroc $\times$ LY \\
\hline \multicolumn{4}{|c|}{$24 \mathrm{~h}$ post mortem } \\
\hline$L^{*}$ & $58.65^{A} \pm 2.06$ & $56.06^{\mathrm{B}} \pm 1.89$ & $55.24^{B} \pm 2.78$ \\
\hline$a^{*}$ & $4.46^{\mathrm{Bb}} \pm 1.02$ & $5.40^{A} \pm 0.70$ & $5.10^{\mathrm{a}} \pm 1.06$ \\
\hline$b^{*}$ & $13.53 \pm 1.76$ & $13.76 \pm 0.55$ & $13.34 \pm 0.60$ \\
\hline$C^{*}$ & $14.60^{\mathrm{ab}} \pm 0.85$ & $14.80^{\mathrm{a}} \pm 0.60$ & $14.32^{b} \pm 0.61$ \\
\hline$h^{0}$ & $70.17 \pm 12.34$ & $68.58 \pm 2.55$ & $69.13 \pm 4.21$ \\
\hline \multicolumn{4}{|c|}{$48 \mathrm{~h}$ post mortem } \\
\hline$L^{*}$ & $58.43^{\mathrm{A}} \pm 2.86$ & $55.28^{B} \pm 1.87$ & $56.36^{\mathrm{B}} \pm 2.88$ \\
\hline$a^{*}$ & $5.37^{B} \pm 1.00$ & $6.53^{\mathrm{A}} \pm 0.58$ & $5.47^{B} \pm 0.82$ \\
\hline$b^{*}$ & $14.36^{A} \pm 0.67$ & $14.37^{A} \pm 0.69$ & $13.66^{B} \pm 0.57$ \\
\hline $\mathrm{C}^{*}$ & $15.36^{\mathrm{Ab}} \pm 0.82$ & $15.79^{\mathrm{Aa}} \pm 0.67$ & $14.74^{B} \pm 0.53$ \\
\hline$h^{0}$ & $69.59^{A} \pm 3.24$ & $65.54^{B} \pm 2.19$ & $68.21^{A} \pm 3.29$ \\
\hline
\end{tabular}

Analysis of color chromatic features 24 hrs p.m. showed at Pulawska fatteners significantly higher redness $\left(a^{*}\right)$ of the LL muscle compared to DanAvl Hybrid pigs and significantly higher color saturation ( $C^{*}$ ) compared to DanAvl Duroc breed. Also $48 \mathrm{hrs}$ after slaughter, the LL muscle of fatteners after Pulawska breed had significantly higher redness $\left(a^{*}\right)$ compared to other groups of hybrid fatteners. In addition, lower yellowness $\left(b^{*}\right)$ and saturation $\left(C^{*}\right)$ of the LL muscle were found in fatteners after DanAvl Duroc boars with reference to DanAvl Hybrids and their hybrids with Pulawska breed.

\section{Sensory characteristics and shear force}

Sensory analysis of LL muscles subjected to thermal treatment showed significantly higher assessment of distinguishing factors, i.e. juiciness, flavor and tenderness at fatteners after pure-breed DanAvl Duroc boars as compared to other analyzed groups of hybrid fatteners, which was also confirmed in instrumental measurement of the shear force (Table 6). In contrast, LL muscles of pigs derived from DanAvl Duroc boars had lower color rating compared to DanAvl Hybrid fatteners and lower aroma rating than DanAvl Hybrids and their hybrids with Pulawska breed. 
Table 6. Sensory assessment and shear force

\begin{tabular}{lccc}
\hline Traits & Group of pigs \\
\hline & DanAvl Hybrid (LY) & Pulawska $\times$ LY & DanAvl Duroc $\times$ LY \\
\cline { 2 - 4 } Colour (pts) & $4.84^{\mathrm{a}} \pm 0.13$ & $4.76^{\mathrm{ab}} \pm 0.25$ & $4.69^{\mathrm{b}} \pm 0.21$ \\
Aroma (pts) & $4.97^{\mathrm{A}} \pm 0.06$ & $4.98^{\mathrm{A}} \pm 0.05$ & $4.70^{\mathrm{B}} \pm 0.16$ \\
Tenderness (pts) & $3.63^{\mathrm{B}} \pm 0.52$ & $3.68^{\mathrm{B}} \pm 0.59$ & $4.13 \mathrm{~A} \pm 0.55$ \\
Juiciness (pts) & $3.42^{\mathrm{b}} \pm 0.49$ & $3.34^{\mathrm{B}} \pm 0.64$ & $3.82^{\mathrm{Aa}} \pm 0.54$ \\
Flavour (pts) & $3.51^{\mathrm{B}} \pm 0.43$ & $3.62^{\mathrm{B}} \pm 0.61$ & $4.07^{\mathrm{A}} \pm 0.42$ \\
Shear force (kg) & $5.14^{\mathrm{A}} \pm 0.76$ & $4.52^{\mathrm{Ba}} \pm 0.52$ & $4.09^{\mathrm{Bb}} \pm 0.69$ \\
\hline A,B Mean values marked by different large letters differ significantly at $p \leq 0.01 ;^{\mathrm{a}, \mathrm{b}}$ Mean values marked by different small letters \\
differ significantly at $p \leq 0.05$
\end{tabular}

\section{Discussion}

\section{Lean content and chemical composition of meat}

In our studies, hybrids derived from DanAvl Hybrid sows and DanAvl Duroc boars obtained a meatiness close to $58 \%$ with a carcass weight of $88.4 \mathrm{~kg}$. Similar carcass meatiness $(58.86 \%)$ of 4433 animals imported from Denmark hybrid pigs - (LY) $\times$ Duroc (D) was found in studies by Bojko and Rekiel (2014). In these studies, it was also shown that participation of carcasses in classes $S$ and $E$ was $92.9 \%$ in total at $94.24 \mathrm{~kg}$ mean weight of carcass in classes. According to the authors mentioned, the obtained results indicate very good, and first of all, repeatable quality of the examined hybrid fatteners in respect of traits that are economically important for meat producers and meat industry. In other studies (Koćwin-Podsiadła et al. 2004b) using material also from Denmark, similar carcass meatiness was found for LY fatteners and their hybrids with Duroc breed and pure-bred fatteners Landrace (from 56.14\% to 56.91\%). Moreover, crossbreeds (LY) $\times \mathrm{D}$ in comparison to maternal group LY had thicker backfat, heavier loin without fat and skin, heavier shoulder and lightest both belly and ham without fat and skin. Cilla et al. (2006) analyzed the quality of carcass and meat of fatteners after Landrace $\times$ Large White sows and pure-bred Duroc boars from three breeding programs. They found that fatteners derived from Duroc from DanBred boars were characterized by better muscularity and lower fat content at similar weight as compared to Duroc boars from other programs. In contrast, Sieczkowska et al. (2010) showed similar meatiness and weight of fattener's carcass after LY sows and pure-bred Duroc boars originated from Danish and Polish pedigree breeding.

In our research, we found the highest IMF content and at the same time the lowest total protein in LL muscle of fatteners after DanAvl Duroc boars. Studies by Koćwin-Podsiadła et al. (2004a) and Grześ et al. (2005) involving material from Denmark, indicate significant effect of pure-bred Duroc boars in crossbreeding with LY sows on the increase in IMF content. In addition, similar IMF content as in our studies for hybrids after Duroc from DanBred boars was obtained by Cilla et al. (2006). Also, the content of total protein and IMF in LL muscle for LY hybrids, similar to our results, was obtained in studies by Koćwin-Podsiadła et al. (2004a), Grześ et al. (2005) and Zhang et al. (2018).

In this study, hybrids after DanAvl Hybrid sows and Pulawska boars were characterized by high carcass meatiness (over 58\%) at carcass weighing around $90 \mathrm{~kg}$. In other studies, there was a lower carcass meatiness of fatteners after pure-bred Pulawska boars in relation to their hybrids with PLW (Florowski et al. 2008) and PL breed sows (Borzuta et al. 2006, Florowski et al. 2008). This is in line with results of studies showing lower meatiness of purebred Pulawska fatteners in relation to pure-bred PL breed ones (Piórkowska et al. 2010, Kasprzyk et al. 2013) as well as PLW, Pietrain and Duroc (Piórkowska et al. 2010). Moreover, in the studies by Babicz et al. (2009) using fatteners slaughtered at a body weight of $135-140 \mathrm{~kg}$, it was shown that cross-breeding of Duroc with Pulawska breed caused an increase in backfat thickness and revealed relatively high gains of ham and loin in relation to total valuable cuts.

In our research, fatteners after DanAvl Hybrid sows and Pulawska boars were characterized by fairly low IMF content and, at the same time, the highest total protein content among the analyzed groups of hybrid fatteners. In other studies, slightly higher IMF content in $\mathrm{m}$. longissimus was found in hybrids after Pulawska sows and PL (1.9\%) and PLW (2.3\%) boars (Florowski et al. 2007) and remarkably higher with Duroc boars (3.05\%) (Babicz et al. 2009). For comparison, the content of IMF in $m$. longissimus was similar for pure-bred fatteners of Pulawska (2.2\%), PL (1.98\%) and PLW breed (2.10\%) (Piórkowska et al. 2010). In other studies, fatteners of Pulawska breed had significantly higher IMF content (3.70\%) in m. longissimus (Florowski et al. 2007) and $2.98 \%$ in $\mathrm{m}$. semimembranosus (Wojtysiak et al. 2016). 


\section{Pork quality characteristics}

In our studies, fatteners after DanAvl Duroc boars had higher pH (24-96 hrs p.m.), lower losses from fresh and thawed meat as well as lower lightness $\left(L^{*}\right)$ of $L L$ muscle as compared to DanAvl Hybrid fatteners. Also in other studies upon material originating from Denmark, the beneficial effect of crossbreeding the LY sows with pure-bred duroc boars with respect to $L Y$ and pure-bred Landrace fatteners had been demonstrated on the physicochemical properties and technological value of meat, as evidenced by lower rate and range of $\mathrm{pH}$ fall, $1.5-2.0 \mathrm{pp}$ lower drip loss and by $1.5 \mathrm{pp}$ higher technological yield in cooking and curing process expressed by technological yield (Koćwin-Podsiadła et al. 2004a). Different research results are presented by Zhang et al. (2018), in which the authors found higher $\mathrm{pH} 45 \mathrm{~min}$ and lower drip loss of $m$. longissimus in LY fatteners as compared to LY $\times \mathrm{D}$. In studies performed by Sieczkowska et al. (2010), more favorable quality of meat was found at fatteners after LY sows and Duroc boars from Danish pedigree breeding than from Polish breeding at similar IMF content and glycolytic resource of LL muscle in 45 min p.m.. In contrast, Cilla et al. (2006) found similar pH (45 min and 24 hrs p.m.) in fatteners derived from duroc boars coming from three breeding programs, however a slightly higher electrical conductivity and lightness $\left(\mathrm{L}^{*}\right)$ of $\mathrm{m}$. longissimus thoracis were found in more leaner hybrids after Duroc boars from DanBred.

In the present study, Pulawska breed was beneficial in crossbreeding with DanAvl Hybrid in respect to the quality of meat as well as reducing the drip loss and darker color $\left(L^{*}\right)$ of LL muscle. In study carried out by Wojtysiak et al. (2016), lower drip loss, shear force and $L^{*}$ values were observed in Pulawska pigs as compared to Pietrain and PLW breeds. These studies have also revealed that muscles of Pulawska pigs are the most oxidative (type I and IIA fibers), but muscles of Pietrain pigs are the most glycolytic ones (type IIB fibers). Ryu and Kim (2005) observed positive relationship between percentage of type IIB fibers and $\mathrm{L}^{*}$, drip loss of $m$. longissimus dorsi. However, research by Florowski et al. (2008) indicate poorer quality of pure-bred Pulawska pigs compared to their hybrids with PLW and PL breeds as evidenced by lower pH (45 min, 24 hrs p.m.) as well as water holding capacity and higher lightness $\left(L^{*}\right)$. Poorer quality of Pulawska pigs meat found in these studies may be related to the aforementioned high frequency of $T$-allele of $R Y R 1$ gene in this breed, which is known to be responsible for the formation of poor meat quality - PSE (pale, soft, exudative).

In our research, on the basis of chromatic analysis of color, it was found that the LL muscles of fatteners after Pulawska breed had the highest redness $\left(a^{*}\right)$, while pigs after DanAvl Duroc boars had the lowest yellowness ( $b^{*}$ ) and saturation ( $\left.C^{*}\right)$. In the studies of Wotysiak et al. (2016), higher a* values in $\mathrm{m}$. semimembranosus were found in Pulawska pigs in relation to Pietrain and PLW breeds. In studies by Zhang et al. (2018), significantly higher a* and $b^{*}$ values were found in the $L Y \times D$ fatteners as compared to LY pigs. The lowest $b^{*}$ for LL muscle at fatteners after DanAvl Duroc found in our study is probably related to the highest pH $24-96 \mathrm{hrs} \mathrm{p.m}$. in this group, better water-holding capacity and lower shear force as compared to LY pigs. As indicated by Ryu and Kim (2005), crossbred $L Y \times D$, yellowness ( $b^{*}$ ) significantly negatively correlates with $\mathrm{pH}$ (45 min and $24 \mathrm{hrs} \mathrm{p.m.)}$ and significantly positively with drip loss and filter-paper fluid uptake (FFU) as well as shear force. In these studies, however, there were no significant relationships between redness ( $\left.a^{*}\right)$ and quality traits, except from positive correlation of $a^{*}$ with FFU. Karamucki et al. (2013) reported significant negative correlations between pH (48 hrs p.m.) and chromatic features of LL muscle $\left(a^{*}, b^{*}\right.$ and $\left.C^{*}\right)$ as well as significant positive relationships between the mentioned color characteristics and IMF.

\section{Sensory characteristics}

The present research has shown the most beneficial sensory quality of tenderness, juiciness and flavor, and the lowest LL muscle cutting force in fatteners after DanAvl Duroc boars. Confirmation of the obtained results is the study by Grześ et al. (2005) involving pigs from Denmark, at which higher tenderness and juiciness values and lower shear force in the meat obtained from the $L Y \times D$ crosses in relation to $L Y$ fatteners, were found. This is probably related to found both in our research and that of Koćwin-Podsiadła et al. (2004a) and Grześ et al. (2005) higher $\mathrm{pH}_{24}$ and water holding capacity, lower cooking losses and higher content of IMF for $\mathrm{LY} \times \mathrm{D}$ hybrids in relation to $\mathrm{LY}$, LY $\times$ Pulawska, Landrace. Zhang et al. (2018) did not find differences between LY and LY $\times D$ hybrids in shear force, at significantly higher $\mathrm{pH} 45 \mathrm{~min}$ and lower drip loss at LY fatteners as well as higher IMF content and marbling at $L Y \times D$ fatteners. Wojtysiak et al. (2016) have shown that IMF is associated with lower drip loss and shear force of m. semimembranosus at Pulawska, which is not confirmed by study of Florowski et al. $(2007,2008)$. They reported that pure-bred Pulawska fatteners were characterized by higher IMF content and worse physicochemical properties of meat as compared to hybrids of that breed with PLW and PL breeds at insignificant difference in shear force. As indicated by the results of Huff-Lonergan et al. (2002), in their research $\mathrm{pH}_{24}$ significantly negatively correlated with the drip loss $(-0.33)$ and cooking loss $(-0.20)$, and positively with tenderness $(0.27)$ and juiciness $(0.25)$. On 
the other hand, drip loss and cooking loss significantly negatively correlated with tenderness scores $(-0.28$ and -0.30 ) and positively with shear force ( 0.29 and 0.34$)$. Moreover, the meat of pig carcasses with a high content of IMF, a factor known to be responsible for lower incidence of pale, soft, exudative meat (PSE) (Jones et al. 1994), but primarily for the higher sensory quality of meat (Fortin et al. 2005). It has been reported that in pork optimum sensory properties are achieved at $2-3.5 \%$ IMF (Wood et al. 1999). In order to obtain the optimum fat content genetically, Duroc pigs may be recommended as one of the most suitable breeds. It has been reported that the fat content and meat quality of pork improves when pigs are at least 50\% Duroc (Warris 2000, Juárez et al. 2009).

\section{Conclusions}

In qualitative studies upon three groups of fatteners with the genotype $C C / R Y R 1$, it was found that hybrid fatteners derived from DanAvl Duroc boars were characterized by the best quality of meat as evidenced by the highest pH determined in 24-96 hrs p.m., the highest evaluation of sensory characteristics of cooked meat - juiciness, tenderness and flavor and the lowest shear force, which probably is related to the highest IMF content found in them. However, the worst quality of meat was found at DanAvl Hybrid fatteners in terms of lightness ( $L^{*}$ ) and drip loss from both fresh and thawed meat. The LL muscle of fatteners after Pulawska breed was characterized by the highest redness $\left(a^{*}\right)$, and fatteners after DanAvl Duroc breed - the lowest yellowness $\left(b^{*}\right)$ and color saturation $\left(C^{*}\right)$.

The presented results unambiguously indicate that pork sourced from all the crossbred groups of pigs was of high quality. All the analyzed crossbreeds contained a desirable amount of IMF, which exceeded $2 \%$ in longissimus lumborum muscles only for the crossbreeds with the DanAvl Duroc breed. The protein content in muscles was also high in all the groups; however, the highest protein contents were affirmed in the meat of fatteners sired by Pulawska boars. The pork from the crossbreeds with DanAvl Duroc and Pulawska boars was normal, with a reddish-pink color. The evaluation of meat acidification confirmed the appropriate process of meat maturation, which is typical for normal meat. To sum up, the obtained results indicate that both DanAvl Duroc and Pulawska boars may be used for crossbreeding with DanAvl Hybrid sows when it comes to the production of high quality meat.

\section{References}

AOAC 2006. Official methods of analysis of AOAC international (18th ed.). Gaithersburg, MD. USA: Association of Official Analytical Chemists (AOAC) International.

Babicz, M., Kamyk, P., Stasiak, A. \& Pastwa, M. 2009. Opportunities to use Puławska pigs for heavy fattener production. Annals of Animal Science 9: 259-268.

Babicz, M., Kropiwiec, K., Kasprzak, K., Skrzypczak, E. \& Hałabis, M. 2013. Analysis of the quality pork obtained from carcasses fatteners of Polish Landrace and Pulawska breed. Annales Universitatis Mariae Curie-Skłodowska Sectio EE 31: 1-7.

Bojko, P. \& Rekiel, A. 2014. Evaluation of productivity of imported crossbred pigs (Landrace $\times$ Yorkshire $\times$ Duroc). Annals of Warsaw University of Life Sciences - SGGW, Animal Science 53: 5-11.

Borzuta, K., Grześkowiak, E., Strzelecki, J., Lisiak, D. \& Buczyński, J.T. 2006. Slaughter traits of dual purpose (meat-fat) pigs derived from current rearing on small-scale farms. Animal Science Papers and Reports 24 (Suppl. 1): $27-33$.

Cebulska, A., Václavková, E., Bocian, M., Dybała, J., Wiśniewska, J. \& Kapelański, W. 2018. Quality and dietary value of pork meat of the Puławska and Złotnicka Spotted breeds, and commercial fattening pigs. Annals of Animal Science 18: 281-291. https:// doi.org/10.1515/aoas-2017-0033

Chang, H.-L., Lai, Y.-Y., Wu, M.-C. \& Sasaki, O. 2017. Genetic correlations between male reproductive traits and growth traits in growth performance tested Duroc, Landrace and Yorkshire breed boars. Animal Science Journal 88: 1258-1268. https://doi. org/10.1111/asj.12776

Cilla, I., Altarriba, J., Guerrero, L., Gispert, M., Martínez, L., Moreno, C., Beltrán, J.A., Guárdia, M.D., Diestre, A., Arnau, J. \& Roncalés, P. 2006. Effect of different Duroc line sires on carcass composition, meat quality and dry-cured ham acceptability. Meat Science 72: 252-260. https://doi.org/10.1016/j.meatsci.2005.07.010

Debrecéni, O., Lípová, P., Bučko, O., Cebulska, A. \& Kapelański, W. 2018. Effect of pig genotypes from Slovak and Polish breeds on meat quality. Archives Animal Breeding 61: 99-107. https://doi.org/10.5194/aab-61-99-2018

Florowski, T., Pisula, A., Rola, M. \& Adamczak, L. 2007. The effect of commercial breed crossing Pulawy pigs with Polish Large White and Polish Landrace on the culinary quality of meat. Roczniki Instytutu Przemysłu Mięsnego i Tłuszczowego 45: 25-34. (in Polish).

Florowski, T., Pisula, A. \& Rola, M. 2008. Comparison of meatiness and the technological quality of pork from Polish Pulawy breed and its crosses with Polish Large White and Polish Landrace pigs. Medycyna Weterynaryjna 64: 673-676. (in Polish).

Fortin, A., Robertson, W.M. \& Tong, A.K.W. 2005. The eating quality of Canadian pork and its relationship with intramuscular fat. Meat Science 69: 297-305. https://doi.org/10.1016/j.meatsci.2004.07.011 
Grześ, B., Pospiech, E., Koćwin-Podsiadła, M., Krzęcio, E., Kurył, J., Łyczyński, A., Mikołajczak, B. \& Iwańska, E. 2005. Comparison of culinary and technological properties of meat from selected genetic groups of pigs. Polish Journal of Food and Nutrition Sciences 14: 55-58.

Huff-Lonergan, E., Baas, T.J., Malek, M., Dekkers, J.C.M., Prusa, K. \& Rothschild, M.F. 2002. Correlations among selected pork quality traits. Journal of Animal Science 80: 617-627. https://doi.org/10.2527/2002.803617x

ISO 4121:2003. Sensory analysis. Guidelines for the use of quantitative response scales. https://www.iso.org/standard/33817.html

ISO 8586:2012. Sensory analysis. General guidelines for the selection, training and monitoring of selected assessors and expert sensory assessors. https://www.iso.org/standard/45352.html

Jones, S.D.M., Tong, A.K.W., Campbell, C. \& Dyck, R. 1994. The effects of fat thickness and degree of marbling on pork colour and structure. Canadian Journal of Animal Science 74: 155-157. https://doi.org/10.4141/cjas94-024

Juárez, M., Caine, W.R., Larsen, I.I., Robertson, W.M., Dugan, M.E.R. \& Aalhus, J.I. 2009. Enhancing pork loin quality attributes through genotype, chilling method and ageing time. Meat Science 83: 447-453. https://doi.org/10.1016/j.meatsci.2009.06.016

Karamucki, T., Jakubowska, M., Rybarczyk, A. \& Gardzielewska, J. 2013. The influence of myoglobin on the colour of minced pork loin. Meat Science 94: 234-238. https://doi.org/10.1016/j.meatsci.2013.01.014

Kasprzyk, A., Babicz, M., Kamyk-Kamieński, P. \& Lechowski, J. 2013. Slaughter value and meat quality of Pulawska and Polish Landrace breeds fatteners. Annales Universitatis Mariae Curie-Skłodowska Sectio EE 31: 1-9. (in Polish).

Kasprzyk, A. \& Łucki, M. 2014. Analysis of the variation of reproductive traits of Danhybryd LY sows. Annales Universitatis Mariae Curie-Skłodowska Sectio EE 4: 7-15. (in Polish).

Koćwin-Podsiadła, M., Sieczkowska, H., Zybert, A., Krzęcio, E., Antosik, K., Łyczyński, A. \& Miszczuk, B. 2004a. Physico-chemical and technological parameters of meat from fatteners obtained on the basis of F0 generation imported from Denmark. Animal Science Papers and Reports 22 (Suppl. 3): 153-159.

Koćwin-Podsiadła, M., Zybert, A., Sieczkowska, H., Krzęcio, E., Antosik, K. \& Włodawiec, P. 2004b. Muscling and carcass composition in fatteners obtained from $F_{0}$ generation imported from Denmark. Animal Science Papers and Reports 22 (Suppl. 3): $147-151$.

Krzęcio, E., Antosik, K., Koćwin-Podsiadła, M., Zybert, A., Sieczkowska, H., Kurył, J. \& Łyczyński, A. 2004. Quality and technological value of meat from porkers of six genetic groups as related to RYR1T gene. Animal Science Papers and Reports 22 (Suppl. 3): 19-30.

Nielsen, B., Su, G., Lund, M.S. \& Madsen, P. 2013. Selection for increased number of piglets at d 5 after farrowing has increased litter size and reduced piglet mortality. Journal of Animal Science 91: 2575-2582. https://doi.org/10.2527/jas.2012-5990

Piórkowska, K., Tyra, M., Rogoz, M., Ropka-Molik, K., Oczkowicz, M. \& Różycki, M. 2010. Association of the melanocortin-4 receptor (MC4R) with feed intake, growth, fatness and carcass composition in pigs raised in Poland. Meat Science 85: 297-301. https:// doi.org/10.1016/j.meatsci.2010.01.017

Prange, H., Jugert, L. \& Schamer, E. 1977. Untersuchungen zur Muskel Fleischqualität beim Schwein. Archiv für Experimentelle Veterinärmedizin. Leipzig 31: 235-248.

Ruan, G.R., Xing, Y.Y., Fan, Y., Qiao, R.M., He, X.F., Yang, B., Ding, N.S., Ren, J., Huang, L. S. \& Xiao, S.J. 2013. Genetic variation at RYR1, IGF2, FUT1, MUC13, and KPL2 mutations affecting production traits in Chinese commercial pig breeds. Czech Journal of Animal Science 58: 65-70. https://doi.org/10.17221/6616-CJAS

Ryu, Y.C. \& Kim, B.C. 2005. The relationship between muscle fiber characteristics, postmortem metabolic rate, and meat quality of pig longissimus dorsi muscle. Meat Science 71: 351-357. https://doi.org/10.1016/j.meatsci.2005.04.015

Sieczkowska, H., Koćwin-Podsiadła, M., Antosik, K., Krzęcio, E., Zybert, A. \& Korszeń, Ł. 2010. Quality of pig carcasses and meat of selected breed groups of fatteners. Roczniki Naukowe Polskiego Towarzystwa Zootechnicznego 6: 363-374. (in Polish).

Szulc, K. \& Skrzypczak, E. 2015. Meat quality of Polish native pigs. Wiadomości Zootechniczne 53: 48-57. (in Polish).

Warris P.D. 2000. Meat Science: an introductory text. Wallingford: Editor CABI Publishing. p. 37-65.

Wojtysiak, D., Górska, M. \& Wojciechowska, J. 2016. Muscle fibre characteristics and physico-chemical parameters of m. semimembranosus from Puławska, Polish Large White and Pietrain Pigs. Folia Biologica (Crakow) 64: 197-204. https://doi.org/10.3409/ fb64_3.197

Wood, J.D., Enser, M., Fisher, A.V., Nute, G.R., Richardson, R.I. \& Sheard, P.R. 1999. Manipulating meat quality and composition. Proceedings of the Nutrition Society 58: 363-370. https://doi.org/10.1017/S0029665199000488

Zhang, J., Chai, J., Luo, Z., He, H., Chen, L., Liu, X. \& Hou, Q. 2018. Meat and nutritional quality comparison of purebred and crossbred pigs. Animal Science Journal 89: 202-210. https://doi.org/10.1111/asj.12878 